\title{
The Role of the Elastase of Pseudomonas aeruginosa in Experimental Infection
}

\author{
John D. Mull ${ }^{1}$ and Walter S. Callahan ${ }^{2}$ \\ Department of Pathology and Bacteriology Laboratory, \\ University of Michigan, Ann Arbor, Michigan
}

\section{Received September 2, 1964}

A characteristic vascular lesion has been described in human systemic infections caused by Pseudomonas aeruginosa (Forkner et al., 1958; Margaretten et al., 1961; Rabin et al., 1961). In an attempt to elucidate its pathogenesis, experimental animals were infected with $P$. aeruginosa to reproduce this vascular lesion. It was found that destruction of the arterial elastic lamina was frequently associated with the lesion, suggesting a probable role of the elastase of $P$. aeruginos $a$ in the pathogenesis. Some of our studies on the elastase of $P$. aeruginosa are reported here.

\section{MATERIALS AND METHODS}

Source of Microorganism. A strain of $P$. aeruginosa, isolated from an infected burn wound of a patient and previously shown to have high elastolytic activity (Mull and Callahan, 1963), was employed.

Preparation of elastase extract. Elastase was prepared from $P$. aeruginosa cultured in nutrient broth $\left(37^{\circ} \mathrm{C}\right.$ for 3 days $)$ by the following fractionation procedure carried out at $4^{\circ} \mathrm{C}$. Slime and bacterial cells were removed by filtration and/or centrifugation and ammonium sulfate ( $400 \mathrm{gm} /$ liter) was added to the supernatant. The precipitate that formed overnight was recovered by centrifugation, dissolved in a small volume of distilled water, and dialysed for 48 hours. After inert material was removed by precipitation with streptomycin sulfate $(10 \mathrm{gm} / \mathrm{liter})$, protein was reprecipitated from the supernatant by the addition of ammonium sulfate (300 $\mathrm{gm} / \mathrm{liter})$ after which the precipitate was redissolved in water, dialysed, and lyophilized. The resulting brown product which was completely water soluble was used in the following assays.

Enzyme assay. Twenty $\mathrm{mg}$ of elastin-orcein (Worthington) and $3 \mathrm{mg}$ of elastase extract dissolved in $3 \mathrm{ml}$ tris buffer | tris (hydroxy-methyl) aminomethane] $0.05 \mathrm{M}$ pH 7.8 were incubated at $37^{\circ} \mathrm{C}$ with gentle shaking for 4 hours. Reactions were stopped by the addition of $2 \mathrm{ml}$ Sorensen's phosphate buffer, $0.7 M \mathrm{pH} 7.0$ (Sacher et al., 1955). Since bacterial pigments present in the enzyme preparation had optical absorption properties similar to that of orcein, the extent of elastolysis was determined indirectly by estimating the remaining undigested elastin-orcein. The undigested

1 Dr. Mull is a Cancer Training Fellow supported by U.S.P.H.S. 2 T1 CA 5083-04.

2 Present Address: Chief, Division of Bacteriology, D. C. Department of Public Health, Washington, D.C. 
elastin-orcein of the reaction mixtures was recovered by centrifugation, washed twice with tris buffer, once with acetone, and then air-dried. The elastin-orcein was then completely digested by incubating with $3 \mathrm{ml}$ tris buffer $0.2 M \mathrm{pH} 8.8$, containing pancreatic elastase ( $2 \mathrm{X}$ crystallized) obtained from the Worthington Biochemical Corp., Freehold, N.J. Optical densities of these reaction mixtures were then determined in a Beckman Model DU spectrophotometer and the per cent of elastin-orcein solubilized was calculated from a standard curve previously prepared from complete digestion of known amounts of elastin-orcein.

Kinetic studies with the elastase of $P$. aeruginosa were carried out as above for a total period of 12 hours during which aliquots were removed at stated intervals. Optimum $\mathrm{pH}$ of the enzyme was established by estimating the activity in the $\mathrm{pH}$ range of $6.7-8.9$, employing tris buffer, $0.05 M$. Temperature optimum of the enzyme was determined at the optimum $\mathrm{pH}$.

Inhibition experiments. Since somc patients, e.g., those with extensive burns, are known to be very susceptible to infections by $P$. aeruginosa, their sera were studied to see if they have lower levels of the elastase inhibitor normally present in human sera (Mandl et al., 1962, Oakley and Banerjee, 1963, Morihara, 1964). For this study, the levels of elastase inhibition of the serum of the following groups were compared: (a) normal adults, (b) patients with recent extensive burns without evidence of $P$. aeruginosa infection, (c) patients with recent extensive burns and with infection of these owing to $P$. aeruginosa, and (d) normal adults vaccinated with a heat-killed culture of a cross-reacting strain of $P$. aeruginosa. Sera of the last group contained a high titer of agglutinating antibodies specific for $P$. aeruginosa. In these studies, the effect of various final dilutions of serum $(1: 10,1: 50,1: 100$, and $1: 200)$ on the extent of hydrolysis of $20 \mathrm{mg}$ elastin-orcein by $1 \mathrm{mg}$ of the elastase extract was estimated. Each serum dilution was assayed in triplicate and controls were set up with all components other than the serum.

Experimental infection with $\mathrm{P}$. aeruginosa. Balb strain mice, each weighing about $20 \mathrm{mg}$, were employed for inducing experimental $P$. aeruginosa infection. Since healthy mice are resistant to infection by $P$. aeruginosa, it was necessary to make them susceptible to this microorganism by pretreatment with 6-mercaptopurine which was shown to alter the inflammatory cycle in rabbits and almost completely eliminate hematogenous mononuclear cell response (Page et al., 1962). The experimental group ( 80 mice) received 8 daily intraperitoneal injections of $0.3 \mathrm{mg}$ 6-mercaptopurine suspended in $0.2 \mathrm{ml} 0.9 \% \mathrm{NaCl}$. After treatment, the mice were divided into three groups. Forty mice received, by subcutaneous injection in the thigh, $0.2 \mathrm{ml}$ bacterial suspension prepared by suspending $P$. aeruginosa cells from a 24-hour growth on nutrient agar in $0.9 \% \mathrm{NaCl}$. Twenty mice were injected similarly with a suspension of one of several common microorganisms (Escherichia coli, Aerobacter aerogenes, Aerobacter cloacae, Streptococcus faecalis, viridans group (Streptococcus mitis), Staphylococcus aureus, and Alkaligenes species). A control group of 20 mice received only 6-mercaptopurine.

The viscera, skin, and entire thighs of the animals were fixed in 10 per cent formalin. The thighs were decalcified in 5 per cent formic acid and serial blocks were sectioned. Sections were stained with hematoxylin and eosin, Voerhoff's elastic stain and Gram's stain. 


\section{RESULTS AND DISCUSSION}

Characterization of the elastase of $\mathrm{P}$. aeruginosa. After an initial lag, the per cent of elastin solubilized approaches a linear relation to time until about 65 per cent of the elastin is solubilized (Fig. 1). The following assays were performed within this linear area. As shown in Fig. 2, the optimum pH of this enzyme is 7.8 in $0.05 M$ tris

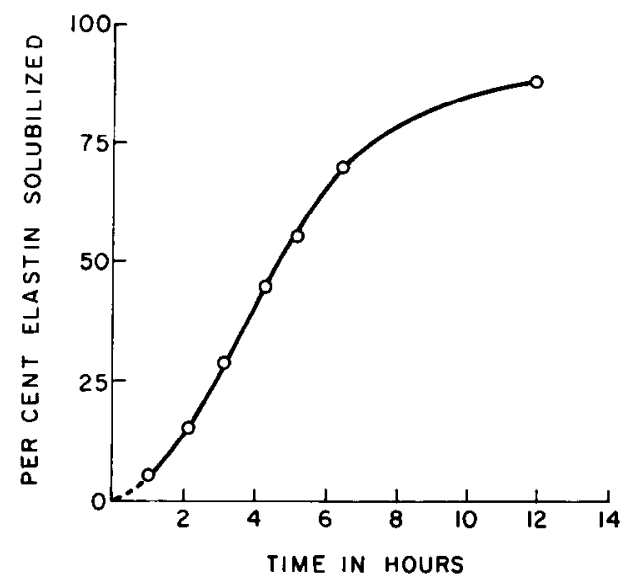

FIG. 1. Time-course study showing the relationship between the extent of elastin-orcein solubilized and time.

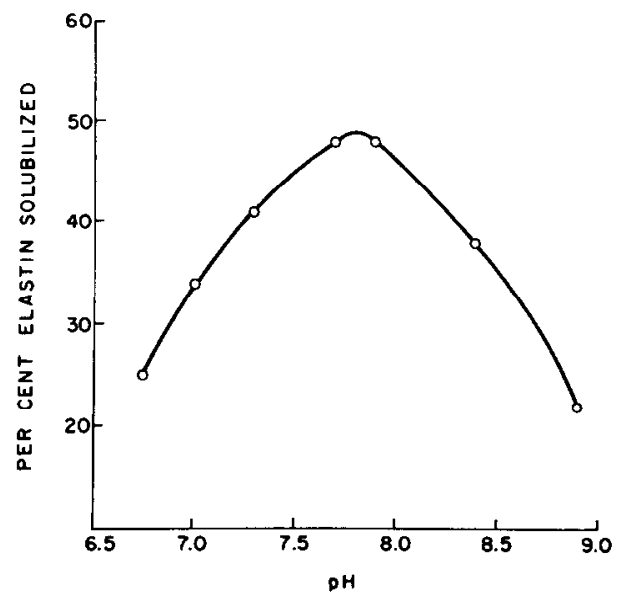

Frr. 2. Curve showing optimum $\mathrm{pH}$ of enzymatic activity with $0.05 \mathrm{M}$ tris buffer.

buffer. Mandl et al. (1962) found a pH optimum of 8.0 in $0.03 M$ tris buffer for an elastase extract from a strain of $P$. aeruginosa isolated from a periodontal socket, and an optimum of 8.5 for an extract from a strain isolated as a collagen digest contaminant. Morihara (1964) found an optimum $\mathrm{pH}$ of 7.5-8.0 in $0.1 M$ tris buffer while Oakley and Banerjee (1963) found the elastase activity of cultural filtrates of $P$. aeruginosa optimal at $\mathrm{pH} 8.5-9.5$. The $\mathrm{pH}$ curve in our study indicates that activity of $P$. acruginosa elastase is near optimum at physiologic pII, thus differing from pancreatic elastase which has optimum activity at $\mathrm{pH} 8.8$. 
The effect of temperature on the enzyme activity is presented in Fig. 3. Elastase prepared from Flavobacterium elastolyticum also exhibits a temperature optimum of 50-55 (Mandl and Cohen, 1960).

The degree of inhibition of $P$. aeruginosa elastase by serum of several groups of human subjects was studied to see if any differences in the level of elastase inhibitor might account for the greater susceptibility of some patients to $P$. aeruginosa infections. The per cent inhibition of elastolysis with 1:10 final dilution of serum was as follows: normal persons, 29-48; burned patients, 25-48; burned and infected patients, 27-50; and normal 'vaccinated' persons, 22-55. At other dilutions of sera also, all four groups exhibited about equal percentages of inhibition: 16-19 with 1:50

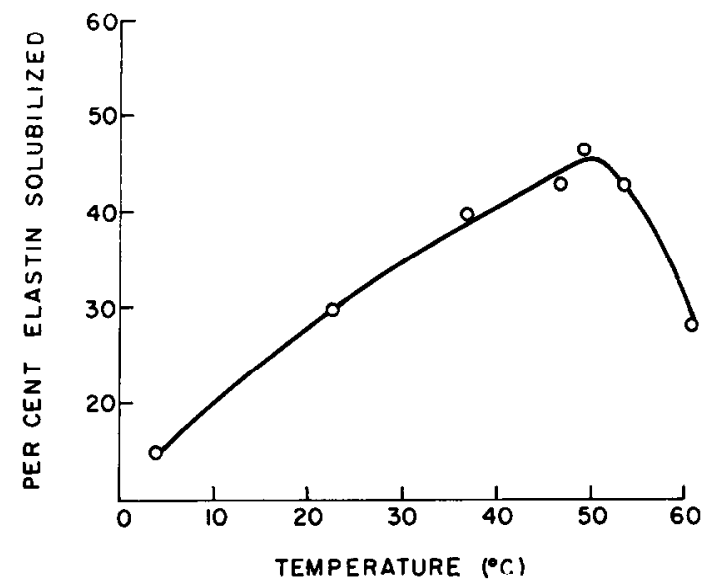

Fig. 3. Effect of temperature on rate of solubilization of elastin-orcein by elastase prepared from $P$. aeruginosa.

dilution, 8-12 at 1:100 dilution, and 3-8 with 1:200 dilution. With human serum in 1:50 dilution, Mandl et al. (1962) found no inhibition of the activity of an elastase produced by a strain of $P$. aeruginosa isolated from a periodontal socket, and only 19 per cent inhibition with the extract of a strain isolated as a collagen digest contaminant. Oakley and Banerjee (1963) found complete serum inhibition of elastolytic activity of cultural filtrates of $P$. aeruginosa only after high concentrations $(1: 2-1: 4)$ of human serum were used. In contrast, pancreatic elastase has been found to be inhibited by low concentrations of human serum. Tolnay and Bagdy (1959) reported 50-90 per cent inhibition of pancreatic elastase with 1:100 dilution of human serum, while Mandl et al. (1962) found 100 per cent inhibition with 1:50 dilution of human serum under their conditions of study. The difference in the serum inhibition of $P$. aeruginosa and pancreatic elastase suggests a basic difference between these two enzymes.

The results of the inhibition study indicate that there is little inhibitor for the elastase of $P$. aeruginosa normally in human serum. Therefore elastolytic activity in human tissue will not be prevented by the presence of serum. In contrast, effective inhibition of pancreatic elastase would be expected. The results also indicate that extensive burns, with and without $P$. aeruginosa infection, and immunization with heat-killed microorganisms do not alter the low level of inhibitor found normally in human serum. 
Histologic studies. The results of the experimental animals treated with 6-mercaptopurine and infected with $P$. aeruginosa is summarized in Table I. Deaths occurred only in the first 3 days and those that survived this period recovered. Almost all deaths were associated with septicemia because of $P$. aeruginosa as indicated by postmortem blood cultures.

TABLE I

Results of Infecting 40 Pretreated Mice with $P$. aeruginosa By Subcutaneous Inoculation

\begin{tabular}{cccc}
\hline $\begin{array}{c}\text { Day after } \\
\text { infection }\end{array}$ & $\begin{array}{c}\text { Total No. of } \\
\text { mice dying }\end{array}$ & $\begin{array}{c}\text { No. of mice } \\
\text { with vasculitis }\end{array}$ & $\begin{array}{c}\text { No. of mice } \\
\text { with bacteremia }\end{array}$ \\
\hline 1 & $16^{a}$ & 15 & 16 \\
2 & $6^{a}$ & 5 & 6 \\
3 & $5^{a}$ & 4 & 4 \\
$4-15$ & $13^{b}$ & 2 & 1 \\
\hline
\end{tabular}

a Mice dying spontaneously.

$b$ Mice sacrificed.

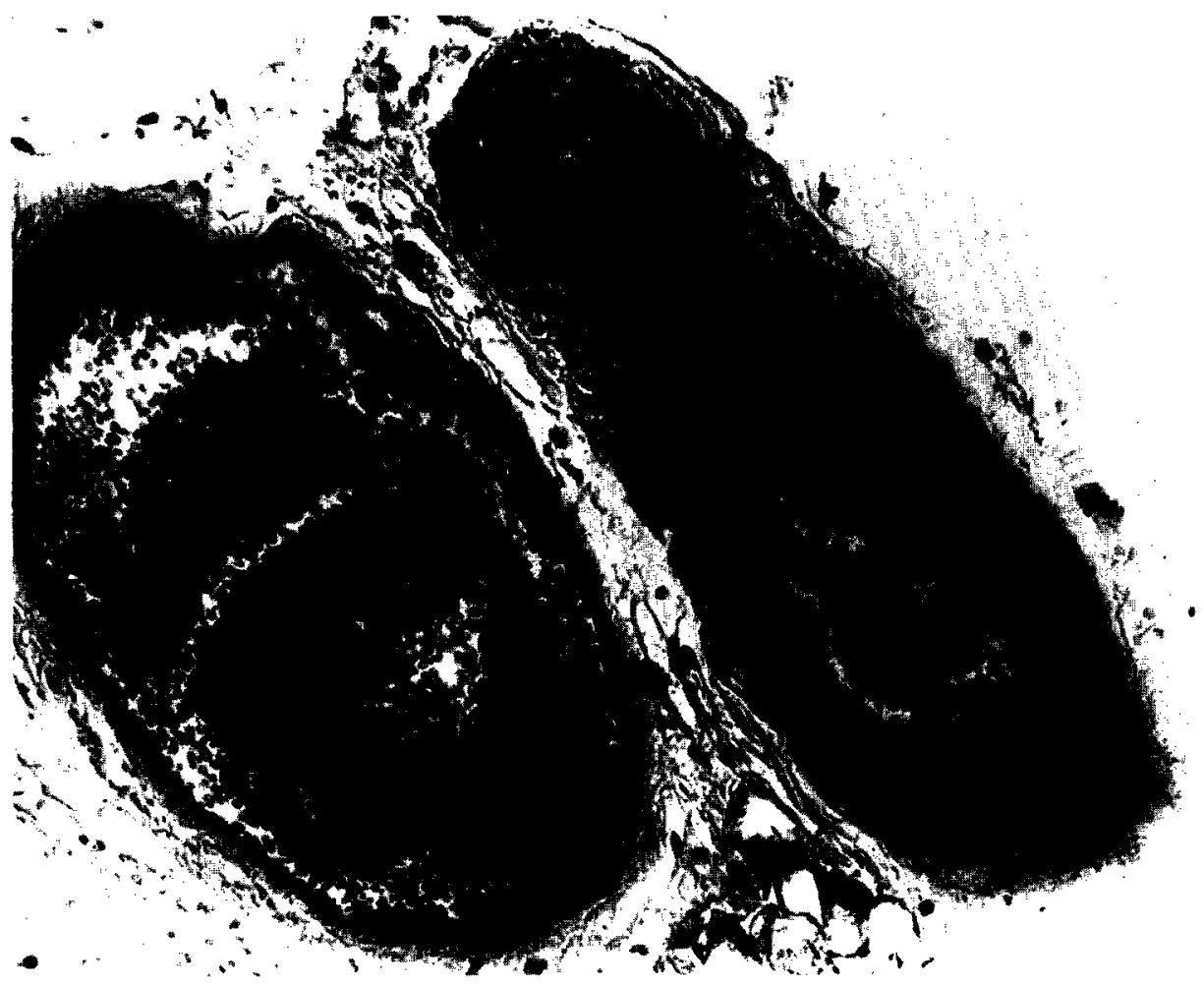

FIG. 4. Large musrular artery and vein from thigh of mouse dying 24 hours after infecting with $P$. aeruginosa. Basophilic clumps of bacteria are present in the arterial wall which also shows early necrosis. Hematoxylin and eosin stain. $\times 300$.

In the tissue sections of the dead mice there was acute purulent inflammation localized to the injection site. A striking vascular lesion was present which set this infection apart from that observed with the other microorganisms used in this study. This lesion was characterized in hematoxylin- and eosin-stained sections by the 
presence of dense basophilic clumps of bacteria in the adventitia and outer media of the walls of the large muscular arteries (Figs. 4 and 5). This 'colonization' was not restricted to the area of the injection site and in fact could be seen to better advantage some distance away. The microorganisms appeared to have tracked along the arteries into areas remote from the main focus of inflammation. Also present in the arteries, although more pronounced in the veins, were necrosis of the vessel wall, adjacent hemorrhage, and early thrombus formation. These changes resemble the 'selective

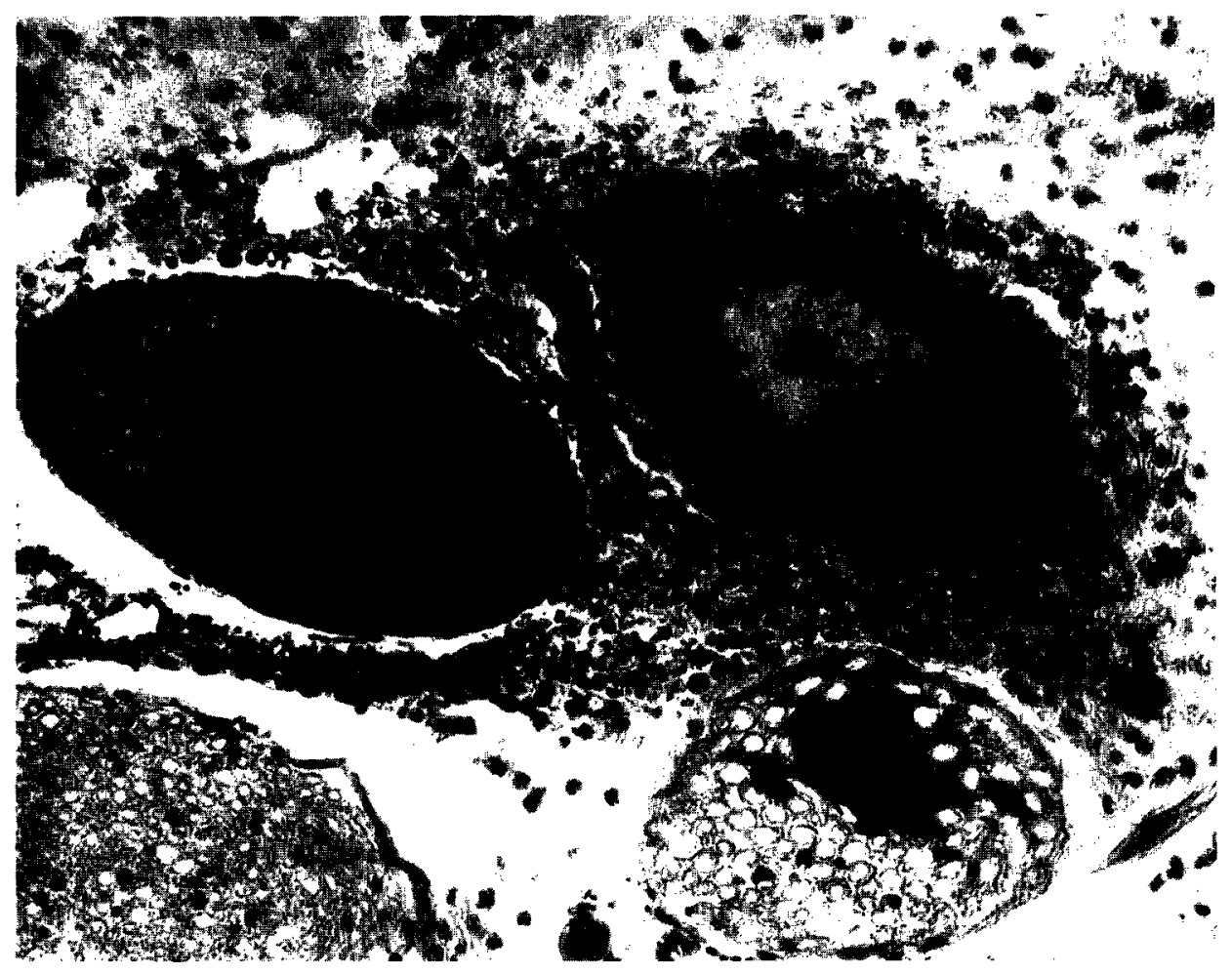

FIG. 5. Artery and vein from the thigh of a mouse dying 48 hours after infection with $P$. aeruginosa. Arterial necrosis, periarterial acute inflammation and hemorrhage are present. The smudginess of the arterial wall is largely due to basophilic clumps of bacteria. Hematoxylin and eosin stain. $\times 280$.

vasculitis' described in human tissues (Forkner et al., 1958; Margaretten et al., 1961; Rabin et al., 1961), although the human lesions result from seeding rather than from local extension of the microorganism.

Further study of the vascular lesion with elastic tissue stains revealed a loss of the arterial elastic laminae (Figs. 6, 7, 8, and 9). This loss was also noted by the absence of brilliant autofluorescent fibers usually seen with fluorescence microscopy. Since $P$. aeruginosa possesses an elastase which is active under physiologic conditions, $P$. aeruginosa is capable of digesting the elastic fibers that constitute important structural barriers in arteries. Although septicemia is most likely the result of the invasion veins at the initial site of infection, arterial invasion results in the formation of thrombi and infarcts, and is associated with the septic infarcts seen in patients as a result of seeding of the microorganisms. 
How

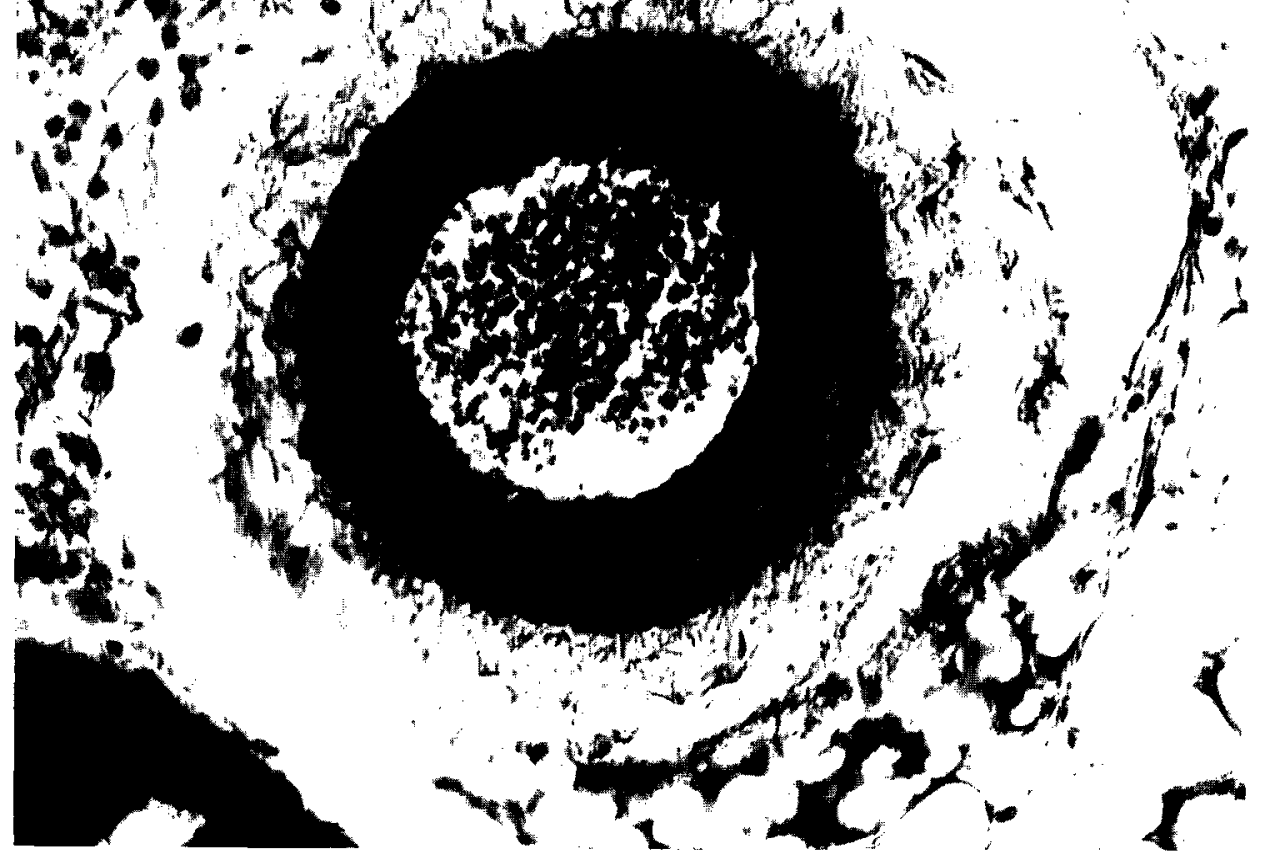

FIG. 6. Large muscular artery from the thigh of a normal control mouse. Voerhoff's elastic stain. $\times 430$.

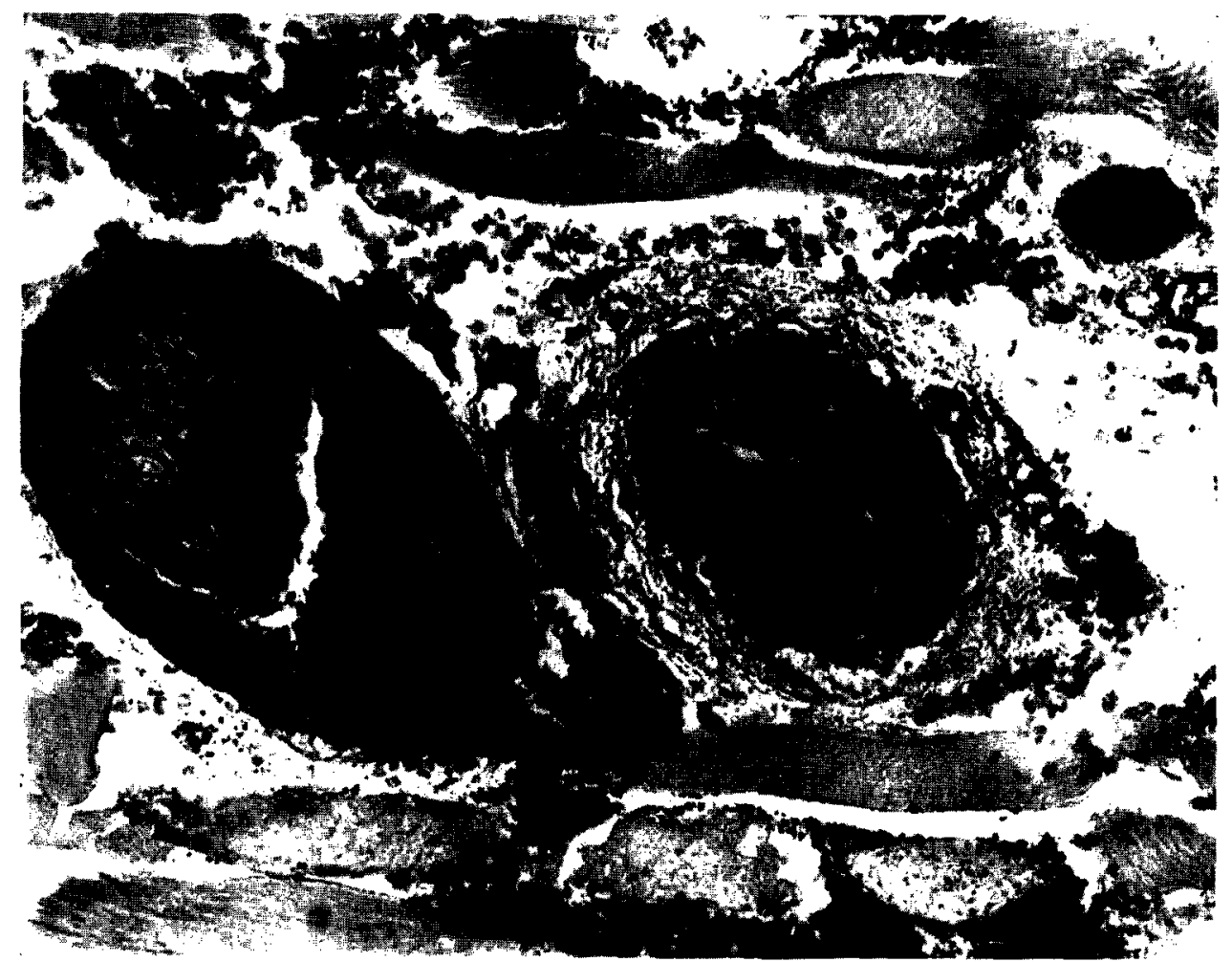

Fig. 7. Artery from a mouse dying at 24 hours. Note the fragmentation and loss of elastic staining material. Voerhoff's elastic stain. $\times 400$. 


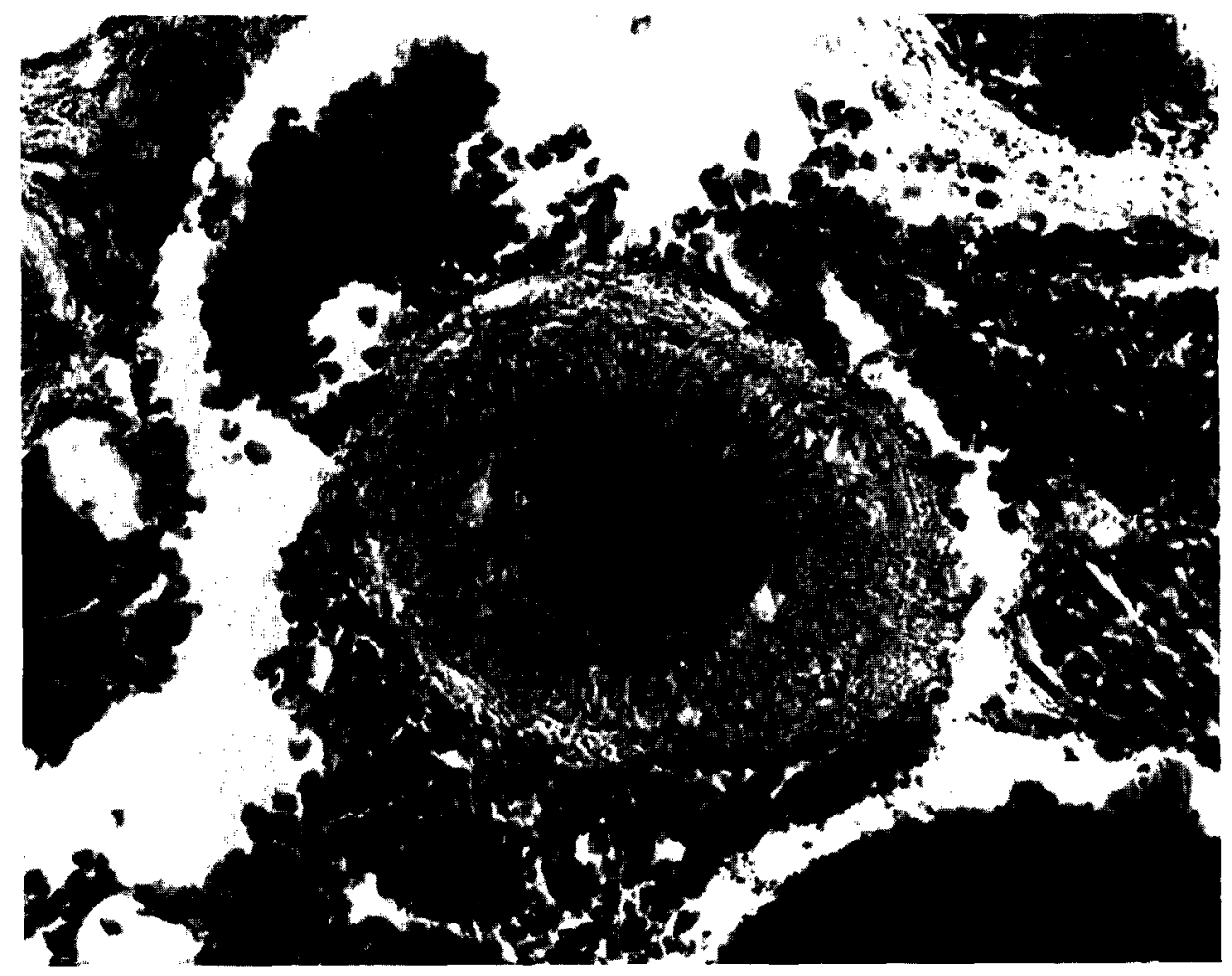

FIG. 8. Similar to Fig. 7, but at 36 hours. The elastic lamina is barely visible. Voerhoff's elastic stain. $\times 630$.

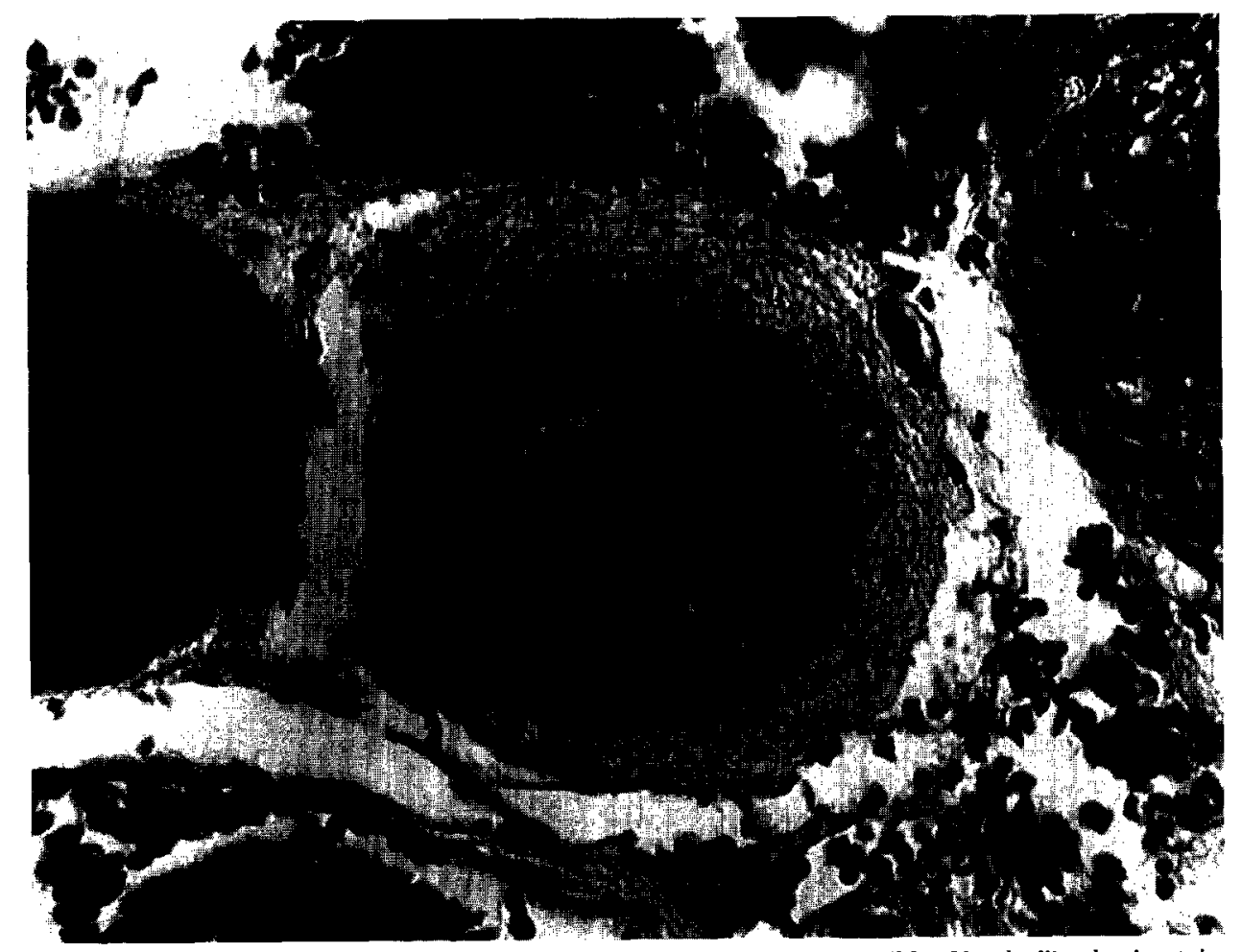

Fig. 9. Similar to Fig. 7, but at 48 hours. No elastic lamina is visible. Voerhoff's elastic stain. $\times 630$ 


\section{SUMMARY}

The characteristic vascular lesion described in human systemic infections due to $P$. aeruginosa has been experimentally produced in mice infected with this microorganism. Since a prominent microscopic finding in the experimental vascular lesions is the destruction of the elastic laminac, the elastase produced by the same pathogenic strain of $P$. aeruginosa was assayed against elastin in vitro. The in vitro studies indicate that the enzymatic activity is near its optimum at physiologic $\mathrm{pH}$ and temperature, and activity is only slightly inhibited by normal human serum. Sera from patients with extensive burns, some infected with $P$. aeruginosa, and from 'vaccinated' human subjects all contained low levels of serum elastase inhibitor similar to normal persons.

\section{ACKNOWLEDGMENT}

We wish to thank Dr. J. Sri Ram for discussion of the biochemical data, and Dr. Bernard Naylor for reading the manuscript.

\section{REFERENCES}

Forkner, C. E., Jr., Frei, E., III, Edgcomb, J. H., and Utz, J. P. (1958). Pseudomonas septicemia: observations on twenty-three cases. Am.J. Med. 25, 877-889.

MANDL, I., and CoHen, B. B. (1960). Bacterial elastase. I. Isolation, purification and properties. Arch. Biochem. Biophys. 91, 47-53.

Mandi, I., Keller, S., and Cohen, B. (1962). Microbial elastases. A comparative study. Proc. Soc. Exptl. Biol. Med. 109, 923-925.

Margaretten, W., NakaI, H., and Landing, B. H. (1961). Significance of selective vasculitis and the "bone-marrow" syndrome in pseudomonas septicemia. New Engl. J. Med. 265, 773-776.

Morihara, K. (1964). Production of elastase and proteinase by P. aeruginosa. J. Bacteriol. 88, 745-757.

Muld, J. D., and Callahan, W. S. (1963). Estimation of elastolytic activity of strains of Pseudomonas aeruginosa. J. Bacteriol. 85, 1178-1179.

Oakley, C. L., and BanerJee, N. G. (1963). Bacterial elastases. J. Pathol. Bacteriol. 85, 489-506.

PAGE, A. R., Condie, R. M., and Good, R. A. (1962). Effect of 6-mercaptopurine on inflammation. Am. J. Pathol. 40, 519-530.

Rabin, E. R., Graber, C. D., Vogel, E. H., Finkelstein, R. A., and Tumbusch, W. A. (1961). Fatal pseudomonas infection in burned patients: a clinical, bacteriologic and anatnmic study. New Engl. J. Med. 265, 1225-1231.

Sacher, L. A., Winter, K. K., Stcher, N., and Frankel, S. (1955). A photometric method for estimation of elastase activity. Proc. Soc. Exptl. Biol. Med. 90, 323-326.

Sbarra, A. J., Baumstark, J. S., Gilfillan, R. F., and Bardawil, W. A. (1963). Elastase production by micro-organisms. Nature 197, 153-155.

Tolnay, P., and BAgDY, D. (1959). On the elastase-inhibiting action of sera. Biochim. Biophys. Acta, 31, 566-568. 